\title{
情報処理スタイル（合理性一直観性）尺度の作成 1),2)
}

内藤 まゆみ

日本学術振興会・

お茶の水女子大学

\author{
鈴 木 佳 苗 \\ 筑波大学図書館情報メディア研究科
}

坂 元 章

お茶の水女子大学文教育学部

本研究は, 合理的処理および直観的処理における個人差（Pacini \& Epstein, 1999）を測定する情報処理ス タイル尺度（IPSI）の作成を目的とした．調查 1 (回答者 290 名) では IPSI38 項目の内容的妥当性を検討す るため, 確認的因子分析を行った。分析の結果, IPSI が合理性と直観性の 2 因子から構成されることが確認 された。また，IPSI は十分な内的一貫性㧍よび再テス卜信頼性を持つことが示された．他の尺度（曖昧さへ の而性と理論志向性，自尊心，社会的望ましさ）との相関は IPSI の収束的・弁別的妥当性を示すむのであっ た．調查 2 (回答者 237 名) では，構成概念妥当性の検討のため, 確率推論課題の回答と IPSI の関連を調べ た。その結果，直観性抄よび合理性が推論エラーの頻度と関連することが示された。加えて，調查 2 では IPSI 短縮版 24 項目を作成し，その信頼性と妥当性が確認された。

キーワード : 情報処理様式, 個人差, 合理的思考, 直観的思考, 2 因子

\section{問 題}

社会的認知の領域では, 1980 年代に人の情報処 理において 2 種類の過程が使われるとする二重過 程モデル（dual-process model）が提案された (Chaiken \& Trope, 1999). それ以後, 多くの二重 過程モデルが提唱されてきた.

例えば, 説得研究では, Petty \& Caccioppo （1984）の精査可能性モデル（Elaboration Likelihood Model: ELM）が広く知られている. ELM で は, 情報の受け手が説得メッセージを能動的に処 理する（精查する）程度によって, 情報処理の方 法が決定される，精査レベルが高ければ，認知的 労力を費やしてメッセージの内容を処理する中心 的ルートがとられる。一方，精査レベルが低い場

1）本研究は, 文部科学省科学研究費助成金（番号 0107709）の援助を受けて行われた。

2) 本研究の一部は, 日本心理学会第 66 回大会にて発 表された。
合には, メッセージの数や送り手の魅力度や専門 性といった周辺的手がかりに基づく処理が行われ る.

近年では, 二重過程モデルをパーソナリティ理 論に発展させた認知的経験的自己理論（CognitiveExperiential Self-Theory: CEST）が提起されている (Epstein, 1994; Epstein, Pacini, Denes-Raj \& Heier, 1996; Pacini \& Epstein, 1999). CEST によれば，人 は 2 つの情報処理様式 一 合理的処理と直観的処 理一をを持ち，この 2 様式を経て自己観や現実観 を構築するとされている.このうち, 直観的処理 は, 全体的, 自動的, 具体的であり, ヒューリス ティックスに基づいた処理を行う様式である。直 観的処理は進化上古くから存在し, 環境への適応 に役立ってきたと考えられている。一方，合理的 処理は, 分析的, 意識的, 抽象的であり, ロジッ クに基づいた処理を行う様式である. 合理的思考 は進化の過程からみると比較的新しく出現したも のとされている. 
この 2 過程の処理について具体例をあげて説明 する.ここに，2つのくじ引き $\mathrm{A}$ と B が目の前に あるとする (Pacini \& Epstein, 1999 を一部改変). $\mathrm{A}$ には 10 個のくじの中に当たりが 1 個入ってい る. B には 100 個のくじの中に当たりが 10 個入っ ている。では，A あるいは B のどちらからくじを 引けば当たると思うだろうか。 B には Aよりも多 くの当たりが入っている，そこで，直観的に考え れば，当たりくじが多いほど当たる確率が高いと いう数ヒューリスティクスに基づき，Bのくじを 選ぶことになる。しかし，双方とも当たる確率は 10 分の 1 であるから，合理的に考えればどちらを 選んでも当たりを引く確率に变わりはないことに なる。

ELM とCEST はともに，2 過程の使用において は動機づけが影響すると主張する（Petty \& Caccioppo, 1984; Pacini \& Epstein, 1999). この動機づ けは，自己にとっての課題の重要性といった状況 的要因や, 特定の様式を遂行しやすいという個人 的要因に左右される（神山，2002 ; Petty \& Wegener, 1999)。例えば，Caccioppo \& Petty（1984） は正しい態度への動機づけを仮定する。そして, その決定因として努力を要する分析的な活動に従 事し楽しむ個人特性, 認知欲求を提案しその尺度 を作成した。 その後の研究で, 高認知欲求者は低 認知欲求者より中心的ルートを経て態度を变容す ることが明らかにされた（Cacioppo, Petty \& Morris, 1983).

しかし，動機づけのタイプはモデルによって相 違がある. ELM は中心的ルートを生起させる正確 志向動機のみを仮定する（Petty \& Caccioppo, 1984; Petty \& Wegener, 1999). 言い換えると, ELM では認知的に簡便な過程への動機づけを仮定して いない。一方, CEST は, 正確さへの動機づけに 加え，複数の動機づけを仮定する，それらは，整 合的・現実的な世界観を維持する欲求，喜びを最 大にし痛みを最小にする欲求, 他者との関係を維 持する欲求，自尊心を維持する欲求である。この
うち, 後者の 3 つの欲求は直観的処理を動機づけ るとされる. CEST が仮定するように，より簡便な 処理を行う動機づけが存在するならば，その状況 的要因や個人的要因の検討が必要である。しかし, 現在のところ二重過程モデルに基礎をおいた個人 的要因を測定する尺度は認知欲求尺度のみであり, 簡便な処理の個人的要因の測定尺度は未だ作成さ れていない。

そこで, Epstein et al. (1996) および Pacini \& Epstein（1999）は，CEST に基づき 2 過程の個人 特性を測定する尺度, 合理性一直観性 ${ }^{3)}$ 尺度 （Rational-Experiential Inventory: REI）を作成した. REI はその信頼性・妥当性が検討されている。例 えば，シナリオに対するヒューリスティックな反 応数と 2 過程の相関を検討したところ (Epstein et al., 1996), 高合理性者はヒューリスティックな反 応数が少なく, 高直観性者はその反応数が多いこ とが示された。ささらに分析を行ったところ，合理 性の影響を統制した後に直観性の影響が検出され た。この結果から，簡便な処理への動機づけを左 右する個人特性が存在し, 合理性とは独立に情報 処理へ影響を及ぼすことが示唆される. 現在, こ れら 2 種類の個人特性を測定する尺度で, 本邦で 使用可能なむのは未だ作成されていない。

以上をふまえ, 本研究では情報処理スタイル尺 度を作成し, 合理的処理および直観的処理の遂行 における個人特性を測定することを目的とする. そのため，2つの調查によって尺度の信頼性・妥 当性の検討を行う。まず, 調査 1 では情報処理ス タイル尺度を作成する. その後, 確認的因子分析 によって尺度の因子構造を確認し, 続いて内的一 貫性と再テスト信頼性, 収束的・弁別的妥当性を 検討する.

3）原文の Pacini \& Epstein（1999）では Experiential で あり，経験性と訳出するのが正確であるが，日本語 として意味が不明瞭であるように思われる。 そこで, 前バージョンにあたる Epstein et al.（1996）で使用 していた Intuition を訳出し直観性とした. 
次に, 調査 2 では構成概念妥当性を検討する. そのため, 確率推論課題を実施し, 確率論および ヒューリスティックスの使用と情報処理スタイル の関連を検討する。また，ここではあわせて尺度 の短縮版の作成も行う.

\section{調査 1}

Pacini \& Epstein（1999）を参考に，情報処理ス タイル尺度の日本語項目を収集する。次に，これ らの項目について, 信頼性および妥当性の検討を 行う.

まず，内容的妥当性を検討する，収集された項 目は合理性と直観性の独立した 2 因子構造をむつ と想定されている（Epstein, 1994; Epstein et al., 1996; Pacini \& Epstein, 1999). しかし, ELMでは 2 過程は連続体上の両極に位置するとし, 両過程 の影響が独立に起こる可能性を否定している（神 山, 2002 ; Petty \& Wegener, 1999).この主張を ふまえれば，情報処理スタイルは合理性と直観性 を両極とする 1 因子で構成されるとも考えられる. そこで， 1 因子構造と 2 因子構造のモデルを想定 し，その比較を行う. 次に，クロンバックの $\alpha$ 係 数および再検査信頼性係数を求め, 尺度の信頼性 を検討する。

また，収束的・弁別的妥当性の検討では，(1)曖 昧さへの耐性, (2)価值志向性尺度の下位尺度であ る理論志向性, (3)自尊心, (4)社会的望ましさとの 相関を求める。(1)曖昧さへの耐性は,「暧昧な事 態を恐れの源泉として知覚 (解釈) する傾向」で あり，この耐性が低いと曖昧な事態を恐れ，規則 のない混乱した状況を避ける。これに対し, 直観 性の項目はこのような状況で直観的に予測や規則 を見つけ出す傾向を測るといえる.したがって， 直観性は曖昧さへの耐性と正に相関すると予想さ れる。(2)理論志向性は，個人が重視すると考えら れる 6 つの価值観のうち, 合理性や論理性を重視 する程度を測定するあのである。ロジックに従う 合理性と正に相関すると予想される。 (3)自尊心は
自己への感情的評価である，自尊心を維持したい という欲求は合理的処理および直観的処理を動機 づけるとされる (Epstein, 1994)。したがって, 双 方の処理と自尊心との正の相関が予想される. (4) 社会的望ましさ尺度は, 合理性・直観性への回答 が社会的に望ましい方に歪められていないか確認 するために使用する. 合理性, 直観性ともに社会 的望ましさとの相関が示されなければ，情報処理 スタイル尺度への回答は社会的望ましさの影響を 受けないといえる。

\section{方 法}

調査回答者 $\mathrm{T}$ 大学々 A大学の学生 290 名（男 性 199 名, 女性 91 名)。このうち久損值が含まれ ていたデー夕を除外し，276名（男性 189 名, 女 性 87 名）を分析対象とした。また，47名には再 検查信頼性の検討のため約 8 週間後に再び調査を 行った.

調查項目 Pacini \& Epstein（1999）により作成 された尺度項目を訳出し, 心理学専攻の大学院生 2 名に (1 名は海外在住経験あり), 訳の自然さな どを確認してもらった，尺度は，論理的，分析的， 意識的な思考を測定する合理性 20 項目と, 直観 的，自動的な思考や感情に基づく判断を測定する 直観性 20 項目から構成される。 それぞれ，下位 項目の能力 10 項目之態度 ${ }^{4)} 10$ 項目を含む. 各項 目について，「1：全くあてはまらない」「2：あ まりあてはまらない」「3：亡゙ちらともいえない」 $\lceil 4$ : 少しあてはまる」「5：非常にあてはまる」の 5 件法で回答を求めた。

妥当性の検討で使用した尺度 (1)曖昧さへの耐 性：今川（1981）によって作成された Ambiguity Tolerance Scale（ATS-IV）の項目のうち, 全体得 点との相関が. 35 以上の 18 項目を使用した. これ らの項目内容について 7 件法で回答を求めた。得

4）原文では, engagement と定義される下位項目である が，項目内容から態度と訳出するのが妥当と判断し た。 
点が高いほど曖昧さへの耐性が高いことを示す. (2)理論志向性尺度：酒井・久野（1997）による価 值志向性尺度の下位項目を用いた。12 項目につい て 5 件法で回答してもらった。得点が高いほど合 理性や論理性を重視することを示す。(3)自尊心尺 度：山本・松井・山成（1982）による日本語版を 用いた。 10 項目について 4 件法で回答を求めた. 高い得点ほど自尊心が高いことを示す。(4)社会的 望ましさ尺度：北村・鈴木（1986）による日本語 短縮版を用いた。10 項目について，「はい」「いい え」の 2 件法で回答を求めた。 高得点になるほど 社会的に望ましいと思われる方向に沿って回答す る傾向が強いとみなされる。

手続き 講義時間の一部を利用して質問紙を配 布し，一斉調査を行った。質問紙は回答後直ちに 回収された。回答には約 30 分を要した。

\section{結果と考察}

項目の選定 項目分析を行うため，合理性の各 項目と，その項目を除いた合理性の合計得点との 相関係数を算出した。直観性の各項目についても 同様に合計得点との相関係数を算出した。その結 果, 合理性・態度 1 項目（「抽象的な言葉で考え るのが好きだ」）と直観性・能力 1 項目（「自分の 予感は，あたることもあたらないことああると思 う」）が各合計得点と有意な相関が得られなかっ た。 また，合理性と直観性それぞれについて G-P 分析を行ったところ，先と同じ 2 項目が有意では なかった。そこで，これらの項目を除く 38 項目 について，以下の分析を行った。

内容的妥当性の検討 情報処理スタイルについ て，その理論的背景から 2 つの因子構造モデルを 想定した（Figure 1 上側）。一つは，合理性と直観 性を両極とする 1 因子から構成されるモデル A で ある.このモデルでは，情報処理スタイル因子か ら合理性項目之直観性項目にパスが引かれる。合 理性項目之直観性項目へのパス係数は正負が逆に なる。他方は，合理性と直観性の 2 因子から構成 されるモデル B である。ここでは，合理性と直観
性が独立した因子とされ，それぞれが合理性項目， 直観性項目へのパスを持つ。そこで，どちらのモ デルがデータへの適合が高いかを明らかにするた め，確認的因子分析によりモデルの比較を行った． デー夕に対するモデル適合度の指標としては, Goodness of Fit Index (GFI), Adjusted Goodness of Fit Index (AGFI), Comparative Fit Index (CFI), Root Mean Square Error of Approximation (RMSEA), Akaike's Information Criterion (AIC) を用いた（Jaccard \& Wan, 1996 ；豊田， 1992）. GFI と AGFI，CFI がとりうる值は 0 から 1 であり， 1 に近づくほどモデルの適合度が高いとされる。 慣例的には.9に近づくのが望ましいとされる。 RMSEA とは数值が 0 に近づくほどモデル適合度が 高いとされる。慣例的には.05に近づくほど望ま しいとされる。また，AICはモデルの比較に使用 できる指標であり，数值が小さいほどよいモデル とみなす。分析では大学と性別を統制した。

その結果，モデル B はモデル A よりも， GFI, AGFI, CFI の值が大きく, RMSEA, AIC の值が小 さかった（Table 1).モデル B はモデル Aよりも デー夕に対する適合度が高いといえる。しかし， 適合度判断の基準に従えば，両モデルの指標は基 準を下回るものであり，当てはまりの良いモデル とはいえない。そこで，十分な適合度を得るよう， モデル B に以下の修正を加えた. Pacini \& Epstein （1999）では，合理性および直観性は 2 つの下位 項目（能力と態度）から構成されている。これに 基づき，モデル $\mathrm{B}$ に能力項目を説明する能力因 子, 態度項目を説明する態度因子を含めたモデル C を想定した（Figure 1 下側). Table 1 に示すよう に，モデル C の適合度は， GFI が.80， AGFI が.74， RMSEA が.06, CFIが.81, AICが -28.897 であっ た。モデルCにおいても望ましいとされる適合度 基準は超えていない。しかし，観測变数が 30 以 上と多くなる場合には GFI や AGFI が低くなるこ とが指摘されている（豊田，1998）。ここでは観 測变数として尺度項目 38 個を用いた分析を行っ 


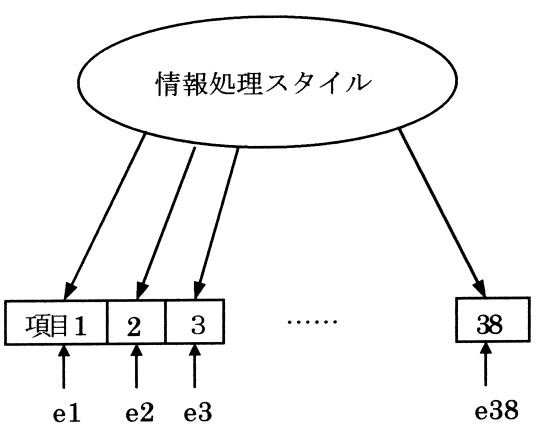

モデル A

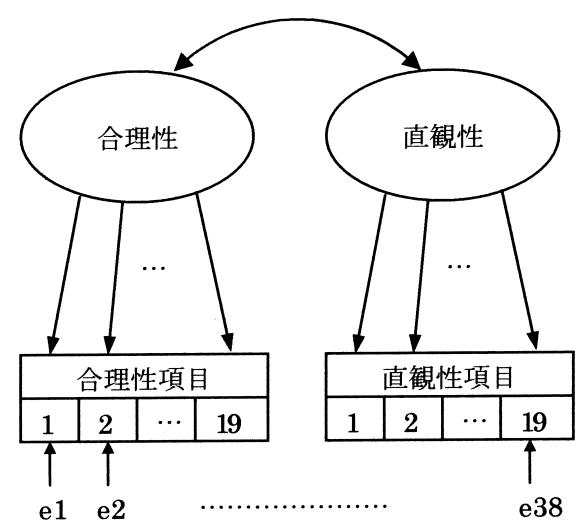

モデル B

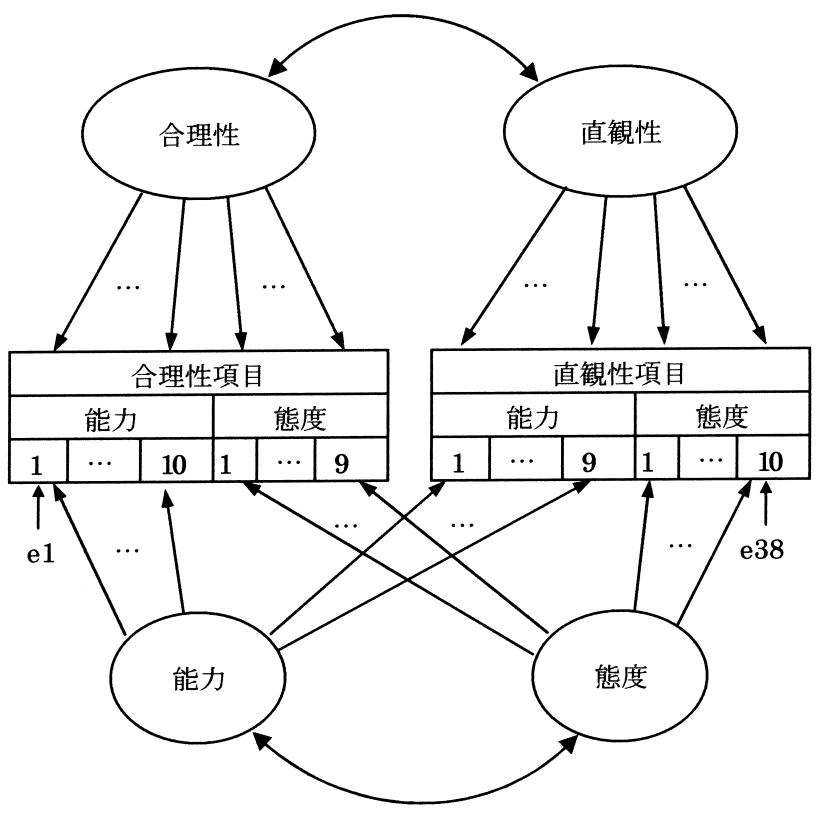

モデル $\mathrm{C}$

Figure 1 情報処理スタイル尺度の因子構造モデル

ており，それゆえ適合度指標が低められたこと屯 推測される。また，Jaccard \& Wan（1996）は複 数の指標を使用してモデルの適合度を判断するよ う勧めている。 モデル C は，GFI や RMSEA は高い 数值ではないが, CFI は.81 と許容可能な值を得て おり, AIC む最む小さい.

以上より，合理性と直観性の 2 因子構造を想定
Table 1 因子構造モデルの適合度指標

\begin{tabular}{cccccc}
\hline & GFI & AGFI & RMSEA & CFI & AIC \\
\hline モデル A & .534 & .425 & .104 & .407 & 1206.427 \\
モデル B & .723 & .658 & .077 & .679 & 350.050 \\
モデル C & .804 & .743 & .061 & .811 & -28.897 \\
\hline
\end{tabular}


Table 2 情報処理スタイル尺度に対する因果係数の推定值

\begin{tabular}{|c|c|c|}
\hline & 合理性 & 直観性 \\
\hline \multicolumn{3}{|l|}{ 合理性 能力 10 項目 } \\
\hline ‥ たいていの人より, あのごとを論理的に解決するのが上手である. & .621 & \\
\hline 7. 論理的な考えの持ち主だ. & .641 & \\
\hline ‥ あのごとを注意深く理論的に解決するのは, 得意ではない. * & .646 & \\
\hline 11. プレッシャーがあると, 論理的に考えることができない.* & .142 & \\
\hline 12. 注意深くものごとを考え抜くのに，困難を感じない. & .349 & \\
\hline 19. 分析的に考える方ではない. * & .674 & \\
\hline 21. 人生や生活上のいろんな問題を考えるとき, 論理的に考えるとうまくいく. & .207 & \\
\hline 23. なぜ自分がそのような決定をしたのか, 明確に説明することができる. & .222 & \\
\hline 29. 複雑な問題を解決するのは, 得意ではない.* & .501 & \\
\hline $\begin{array}{l}\text { 39. 注意深く論理的な分析が必要とされる問題を解決するのは, 得意ではない.* } \\
\text { 合理性 態度 } 9 \text { 項目 }\end{array}$ & .614 & \\
\hline 1. 何かについて深く考えなければならない状況を避けようとする.* & .140 & \\
\hline ‥ 簡単な問題より複雑な問題の方が好きだ. & .286 & \\
\hline 16. 何かについて一生懸命かつ長時間考えても, 満足感は得られない. * & .041 & \\
\hline 18. 答えを知っていれば，その理由が理解できなくてもかまわない．* & .256 & \\
\hline 24. 考えることは，楽しいことだと思わない．＊ & .268 & \\
\hline 28. 私にとって, 新しい考え方を学ぶことは, とても魅力的である. & .354 & \\
\hline 30. 知的な挑戦が好きだ. & .406 & \\
\hline 吕. 一生懸命考えなければならないような問題を解決するのが好きだ. & .373 & \\
\hline 婴. いろいろ考えるのは好きではない．* & .308 & \\
\hline \multicolumn{3}{|l|}{ 直観性 能力 9 項目 } \\
\hline ‥ 自分の予感を信じることにしている. & & .514 \\
\hline 13. 私のとっさの判断は, たいていの人より良くないだろう。* & & .217 \\
\hline 14. たいていの場合, 人を信頼するかどうか, 直観に頼って決める. & & .289 \\
\hline 15. なぜだか理由を説明できないが, その人が正しいか間違っているかを, 感じとることができる. & & .283 \\
\hline 20. 私にはすごい直観力はない．＊ & & .493 \\
\hline 33. 屯し私が直観に頼るならば，間違いを怙かすことが多くなるだろう。* & & .545 \\
\hline 年. 答えをみつけるために直観に従って，うまくいかなかったことはほとんどない. & & .358 \\
\hline 37. 人生や生活上のいろんな問題を考えるとき, 直観的にやるとうまくいく. & & .542 \\
\hline 38. 人に対する第一印象を信じる. & & .234 \\
\hline \multicolumn{3}{|l|}{ 直観性＼cjkstart態度 10 項目 } \\
\hline 2. 自分の直観に頼った方がいい時があると思う. & & .503 \\
\hline 4. 直観に頼らなければならない状況は好きではない.* & & .581 \\
\hline 10. 何かについて決定する時に, 感情に頼ることはない＊＊ & & .343 \\
\hline 17. 自分自身を直観的な人間だという人を信頼したくない＊* & & .471 \\
\hline 22. 行動の指針として感情に頼りがちである. & & .442 \\
\hline 25. 直観は問題を解決するのに役立つ方法だろう. & & .675 \\
\hline 26. 感情に基づいて重要な決定をするのは, 愚かなことだと思う.* & & .466 \\
\hline 27. 行動を決める時，直観に頼ることが多い. & & .650 \\
\hline 32. 直観に頼って重要な決定をするのは, いい考えだと思わない，* & & .644 \\
\hline 34. 直観的な印象に頼るのが好きだ. & & .703 \\
\hline
\end{tabular}

注. *は逆転項目. 下線は短縮版の項目. 
Table 3 情報処理スタイル尺度の平均值と標準偏差, および $\alpha$ 係数と再テスト信頼性

\begin{tabular}{|c|c|c|c|c|}
\hline & 平均値 & 標準偏差 & $\alpha$ 係数 & テストー再テスト相関係数 \\
\hline 合理性 & 65.43 & 10.67 & .85 & .79 \\
\hline 能力 & 31.70 & 6.57 & .82 & .74 \\
\hline 態度 & 33.73 & 5.60 & .75 & .66 \\
\hline 直観性 & 57.69 & 11.19 & .85 & .76 \\
\hline 能力 & 25.30 & 5.47 & .69 & .64 \\
\hline 態度 & 32.38 & 7.03 & .82 & .76 \\
\hline
\end{tabular}

Table 4 情報処理スタイル尺度と各尺度の相関係数

\begin{tabular}{|c|c|c|c|c|}
\hline & 曖昧さへの耐性 & 理論志向性 & 自尊心 & 社会的望ましさ \\
\hline 合理性 & .03 & $.64 * *$ & $.31 * *$ & .00 \\
\hline 能力 & -.01 & $.52 * *$ & $.38 * *$ & -.02 \\
\hline 態度 & .08 & $.60 * *$ & $.15 *$ & .02 \\
\hline 直観性 & $.25 * *$ & .01 & $.20 * *$ & .04 \\
\hline 能力 & $.14 *$ & .04 & $.33 * *$ & .06 \\
\hline 態度 & $.28 * *$ & -.02 & .06 & .02 \\
\hline
\end{tabular}

$* * p<.01 ; * p<.05$

したモデル C を情報処理スタイル尺度の因子構造 として採用した。 2 因子モデルでの合理性と直観 性の相関は -.23, 能力と態度の相関は. 47 であっ た. Table 2 に合理性之直観性から各項目への因果 係数の推定值 ${ }^{5)}$ を示した。因果係数が大きいほ よ゙，その因子が各項目に及ぼす影響量は大きい。

信頼性の検討 合理性と直観性および下位項目 の平均值と標準偏差, クロンバックの $\alpha$ 係数, テ ストー再テストの相関係数を Table 3 に示す. 合

5）この数値は探索的因子分析に抢ける因子負荷量とは 異なる。机は，分析上想定しているモデルが異な るためである。確認的因子分析のモデルでは，ある 概念を測定する項目には，その当該概念からのみパ スが引かれる。本文でいえば，合理性項目には「潜 在変数：合理性」からのみパスが引かれる. 同様に, 直観性項目には「潜在変数：直観性」からのみパス が引かれる。一方, 探索的因子分析のモデルでは, ある概念を測定する項目に当該概念以外からあパス が引かれる，本文でいえば，合理性項目に「潜在変 数：直観性」からあパスが引かれ，直観性項目に 「潜在変数: 合理性」からあパスが引かれているモデ ルになる。
理性全体の $\alpha$ 係数は.85, その能力項目は.82, 態 度項目は.75 であった。直観性全体の $\alpha$ 係数は.85, 能力項目は.69, 態度項目が.82 であった。また, テストー再テストの相関係数は, 合理性全体が.79, 能力項目が.74, 態度項目は.66であり, 直観性全 体が.76, 能力項目が.64, 態度項目は.76であっ た. 以上の結果から, 情報処理スタイル尺度は十 分な内的一貫性と安定性を備えた尺度といえる。

収束的・弁別的妥当性の検討 曖昧さへの耐 性, 理論志向性, 自尊心, 社会的望ましさの 4 尺 度と情報処理スタイル尺度の相関係数を算出した。 分析では大学と性別を統制した. Table 4 に示すよ うに，直観性全体および下位項目之曖昧さへの耐 性は有意な正の相関を示した。合理性全体および 下位項目と理論志向性にも有意な正の相関がみら れた。 また, 直観性・態度項目を除き, 情報処理 スタイルと自尊心との間に有意な正の相関がみら れた。これらの相関はいずれも理論的に予測され たものと一致していた。自尊心と直観性・能力項 目との間には相関がみられなかったが，この結果 が本調査のみのものなのかどうか今後の検討が必 
要である，ただし，直観性全体としては有意な相 関が得られており, 直観性・態度項目は情報処理 スタイル尺度を構成する設問として妥当であると 考えられる。また，合理性と直観性，およびそれ らの下位項目は社会的望ましさとの間に相関がな く，本尺度への回答が社会的に望ましい方向に歪 められないことが示された。 以上の結果から，情 報処理スタイル尺度は十分な収束的・弁別的妥当 性をむつことが確認されたといえる。

\section{調査 2}

確率論・ヒューリスティックスの使用と情報処 理スタイルの関連を検討するため, 確率判断課題 を実施する。課題には，リンダ問題（Tversky \& Kahneman, 1982） と事象問題（Epstein, Denes-Raj \& Pacini, 1995）を使用する.

リンダ問題では, 人物（リンダ）のパーソナリ ティに関する記述を読み，パーソナリティとの類 似度が高い行動を記述した事象 $\mathrm{A}$, 類似度の低い 行動を記述した事象 B, 両方を含む事象 A \& B , これら 3 つの行動のうち, 生起確率が高いと思わ れる順で順位づけをする。事象課題では, 起こり やすい事象 A と起こりにくい事象 $\mathrm{B}$, および A と B が同時に起こる事象 A \& B の 3 つについて, 起 こる確率の順位づけを求める。まず，A＆ B が最 屯起こりにくいとの順位づけは，2つの事象が同 時に起こる確率は単一事象の確率より低いという 確率論に従った推論である。したがって，この順 位づけでは合理的処理が行われたと考えられる. 一方，A＆Bの方が A または B よりも起こりやす いとの順位づけは，確率論からみれば誤りである ため, 連言錯誤（Conjunction Error: CE）と呼ば れている.リンダ問題においては，CE は類似度の 高い A を含む A \& B の方が類似度の低い単一事象 B よりも起こりやすいとする，代表性ヒューリス ティックを使用するために生じるとされる（Tversky \& Kahneman, 1982). したがって，リンダ問題 での CE は直観的処理を表すむのとみなす。事象
問題は抽象的な文章により教示するため, ここで の CE は代表性ヒューリスティックによるもので はない.しかし，このCEは「起こりやすい事象 A が含まれている A \& B の生起確率が高い」との 判断がなされた結果と考えられる。これは単体事 象 A の生起確率に影響されたものであり，いわば 起こりやすさヒューリスティックとあみなしうる. したがって, 事象問題における $\mathrm{CE}$ 屯直観的処理 を示すむのとする.

本尺度が情報処理スタイルを適切に測定するな らば，順位づけにおいて，高直観性者は CE が多 く高合理性者は CEが少ないと予想される。ただ し，合理的な順位づけ（あるいは，直観的な順位 づけ）であっても，実際は確率論に（ヒューリス ティックに）基づいていない判断かもしれない. そこで, 順位づけに続けてその理由を尋亦, 直観 性と合理性が及ぼす影響について検討する。また， ここでは情報処理スタイル尺度の短縮版を作成し， 本尺度との相関および確率推論課題との関連も検 討する.

\section{方 法}

調査回答者 $\mathrm{T}$ 大学の学生 237 名（男性 121 名, 女性 116 名)。このうち久損值が含まれてい たデー夕を除外し，232 名（男性 119 名, 女性 113 名）を分析対象とした。

材料 2 種類の確率推論課題を用いた。 それぞ れの記述文は以下の通りである.

リンダ問題「リンダは 31 歳, 独身, 率直で たいへんに聡明な人である。彼女は大学で哲学を 専攻した。学生時代には, 差別や社会的公正の諸 問題に深い関心を持ち，反核デモにも参加した」. リンダは（a）男女同権運動をしている，(b) 銀 行の出納係である, (c) 銀行の出納係であり, 男 女同権運動をしている.

事象問題「過去の結果によると，A は起こり やすい出来事であり, B は起こりにくい出来事で あることがわかっている」. (a) 出来事 Aが起こ る, (b) 出来事 B が起こる, (c) 出来事 $\mathrm{A}$ と出来 
Table 5 確率推論課題における連言錯誤（CE）の有無の測定值

\begin{tabular}{|c|c|c|c|c|}
\hline & \multicolumn{2}{|c|}{ リンダ問題 } & \multicolumn{2}{|c|}{ 事象問題 } \\
\hline & CEなし & CE あり & CEなし & CE あり \\
\hline \multicolumn{5}{|l|}{ 直観性 } \\
\hline 低群 & 82 & 36 & 100 & 19 \\
\hline 高群 & 61 & 51 & 92 & 21 \\
\hline \multicolumn{5}{|l|}{ 合理性 } \\
\hline 低群 & 68 & 49 & 90 & 29 \\
\hline 高群 & 75 & 38 & 102 & 11 \\
\hline
\end{tabular}

事Bの両方が起こる.

回答者は全ての問題を読み，(a)，(b)，(c) に ついて起こる確率の高い順に 1 3 まで番号をつけ た. また, その順位づけの理由も記述した。

情報処理スタイル尺度 調查 1 で作成した 38 項目尺度を使用した。

手続き 調査 1 と同様に, 講義時間を利用して 調查を行った. 回答時間は 30 分程度であった。

\section{結果と考察}

順位づけ 各問題で（c）の順位が 1 または 2 番目の場合を $\mathrm{CE}$ とした ${ }^{6)}$. 各情報処理スタイル 得点の中央值（合理性 62 点, 直観性 58 点）を基 準に, 合理性高群と合理性低群, あるいは直観性 高群と直観性低群に分けた. Table 5 に, CE の有 無と情報処理スタイルのクロス分割表を問題別に 示した.

次に, Table 5 における度数について, 問題別に 対数線形モデル分析を行った. 対数線形モデル分 析とは, 分割表で表せるデー夕を分析できる手法 である（SAS インスティチュートジャパン，1993）.

6）代表性ヒューリスティクスの影響を受ける場合, A の方がリンダとの類似度が高いため, A \& B の方が Bよりも生起確率が高く推定される. しかし, 回答 者によってはBの方がリンダとの類似度が高いと予 想していた（「頭のいい女性だから社会に出たら利益 を得られるようにふるまう」など)。そのため，A＆ B の方が B よりも生起確率が高いと回答した場合む CE とみなした。ただし，こうした回答者は少数であ り，これらのデー夕を除いた分析でも本文と同様の 結果が得られた.
対数線形モデル分析は, 複数のカテゴリーに分け られる測定值に対して, 独立变数の主効果扔よび 交互作用が効果を及ぼしているのか検定すること ができる.

リンダ問題での度数を従属变数とし, 合理性, 直観性, CE の有無の主効果および交互作用を独 立变数とした対数線形モデル分析を行った。 その 結果, 直観性 $\times \mathrm{CE}$ の交互作用が認められた $\left(\chi^{2}(1)=4.49, n=230, p<.05\right)$. Table 5 左側から, 直観性低群では CE なし群が CE あり群を大きく上 回っており, 直観性高群では CE なし群と CE あり 群の差が縮まっていた。この結果から, 直観性低 群ではヒューリスティックを使用した直観的判断 を行う者が少なく CE の出現が抑えられたのに対 し, 直観性高群ではヒューリスティックに基づく 判断を行う者が多く CEが増加したと考えられる. したがって，この結果は当初の予想を支持するも のといえる. 合理性の主効果㧍よび他の要因との 交互作用はみられなかった。

事象問題について, 上記と同様に対数線形モデ ル分析を行ったところ, 合理性 $\times \mathrm{CE}$ の交互作用 が有意であった $\left(\chi^{2}(1)=8.00, n=232, p<.01\right)$. Table 5 右側から, 事象問題では合理性低群に比べ 合理性高群は CE が少ないといえる。これは当初 の予想を支持する結果であった. 直観性の主効果 および他の要因との交互作用はみられなかった。

順位づけの理由評定者 2 人が, 順位づけの理 由を(1)確率論, (2)ヒューリスティックス, (3)その 他の 3 種類にコード化した. 評定者間の一致率は 
Table 6 確率推論課題における順位づけ理由の測定值

\begin{tabular}{|c|c|c|c|c|}
\hline & \multicolumn{2}{|r|}{ リンダ問題 } & \multicolumn{2}{|r|}{ 事象問題 } \\
\hline & 確率論 & ヒューリスティック & 確率論 & ヒューリスティック \\
\hline \multicolumn{5}{|l|}{ 直観性 } \\
\hline 低群 & 60 & 42 & 89 & 13 \\
\hline 高群 & 45 & 37 & 67 & 15 \\
\hline \multicolumn{5}{|l|}{ 合理性 } \\
\hline 低群 & 47 & 44 & 71 & 20 \\
\hline 高群 & 58 & 35 & 85 & 8 \\
\hline
\end{tabular}

約 93\% であった，不一致の場合は，評定者の話し 合いによってカテゴリーを決定した. Table 6 に, 順位づけの理由と情報処理スタイルのクロス分割 表を問題別に示した。

次に，問題別に順位づけと同様の対数線形モデ ル分析を行った。リンダ問題では有意な効果がみ られなかった。事象問題では理由の種類 $\times$ 合理性 の交互作用が得られた（ $\chi^{2}(1)=5.47, n=184$, $p<.05)$. Table 6 右側から, 合理性低群に比べ合 理性高群は確率論を多く理由にあげるといえる。 直観性の主効果および他の要因との交互作用はみ られなかった。

これらの結果から，高直観性者は CE が多いこ とが示され，ヒューリスティックスに基づく処理 をすることが示唆された。一方，高合理性者は CE が少なく，順位づけの理由として確率論に多く言 及することが示された。これらの情報処理スタイ ルと確率推論の関連は予想に一致するあのであっ た.

\section{情報処理スタイル尺度短縮版の作成}

調查 1 の確認的因子分析の因果係数之項目内 容, 逆転項目の数を考慮し, 合理性 12 項目々直 観性 12 項目の計 24 項目を短縮版とした（Table 2). 短縮版のクロンバックの $\alpha$ 係数は合理性が.86 (能力は.86, 態度は.77), 直観性が.84（能力 は.73，態度は.80）であった。また，調査 1 と調 査 2 の両方に回答した 29 名を対象に, 本尺度と 短縮版の相関を算出した。合理性の相関が.77（能 力と態度はともに.71），直観性の相関は.70（能力
が.59，態度が.70）であった

短縮版と確率推論の関連を本尺度と同様に分析 したところ，リンダ問題の順位づけにおいて直観 性 $\times \mathrm{CE}$ の交互作用がみられた $\left(\chi^{2}(1)=2.98\right.$, $n=231, p<.08)$. 事象問題の順位づけにおいては 合理性 $\times \mathrm{CE}$ の交互作用がみられた（ $\chi^{2}(1)=3.97$, $n=232, p<.05)$. また, 事象問題の理由に関して, 合理性 $\times$ 理由の種類の交互作用がみられた $\left(\chi^{2}(1)=3.08, n=184, p<.08\right)$. これらの結果は本尺 度と同様のものであった，以上より，短縮版の信 頼性と妥当性が確認されたといえる.

\section{総合的考察}

本研究では, 情報処理スタイル尺度の作成およ び信頼性・妥当性の検討を目的とし, 調査 1 と調 查 2 を実施した。調査 1 では, 38 項目を収集し, 確認的因子分析を行った。 その結果, 尺度が 2 因 子から構成されることが示され, 内容的妥当性が 確認された。 また，クロンバックの $\alpha$ 係数，テス ト一再テストの相関係数から，本尺度が十分な内 的一貫性および安定性をむつことが認められた。 妥当性の検討では, 暧昧さへの耐性, 理論志向 性, 自尊心，社会的望ましさの 4 尺度との相関を 算出した，結果は予測に一致するものであり, 尺 度の収束的・并別的妥当性が確認された。調查 2 では, 処理スタイルが確率推論に与える影響を検 討した。分析の結果, 高直観性者は低直観性者よ り CE の頻度が高いこと, 高合理性者は低合理性 者より $\mathrm{CE}$ の頻度が低く, より確率論を使用する 
ことが示された。 また，あわせて短縮版の作成を 行い, 内的一貫性および本尺度との十分な相関, 確率判断との関連が認められた.

調查 2 では問題により異なる結果を得た。すな わち, リンダ問題では直観性の効果のみが示され, 事象問題では合理性の効果のみが示された。これ は設問が具体的か抽象的かという文章の性質に起 因すると考えられる。パーソナリティ記述のよう な具体的文章は, 高直観性者にとって判断の手が かりとなり, 態度変容を起こしやすいとの議論が ある (Epstein et al., 1996). 同様に, 抽象的文章 は高合理性者にとって判断の手がかりとなるとい える。 そうであるならば，リンダ問題は高直観性 者の情報処理を活性化させ, 事象問題は高合理性 者の情報処理を活性化させるのかもしれない.こ の予測は調査 2 の結果と合致するあのであり, 問 題による結果の相違は本尺度の妥当性を示すあの と考えられる. 以上の結果から, 情報処理スタイ ル尺度およびその短縮版は, 高い信頼性と妥当性 を備えた尺度であるといえる。

しかしながら，尺度の因子構造に関しては，さ らなる検討が必要であると考えられる。研究 1 で は 2 因子構造モデルを採択したが, よりデー夕に あてはまるモデルが存在する可能性は否定できな い. 因子構造の検討は， 2 過程が独立しているか 否か (Pacini \& Epstein, 1999; Petty \& Wegener, 1999）という二重過程モデルでの未解決課題を解 決する手段になりうる. 今後の検討によって最適 な因子構造モデルが検出されることが望まれる.

ELM を含め多くの二重過程モデルでは, 簡便な 情報処理は推論エラーやバイアスの原因とみなさ れ (Smith \& DeCoster, 1999), その動機づけは想 定されてこなかった。これは, 人は正確さを求め る存在と前提され (Petty \& Caccioppo, 1984; Petty \& Wegener, 1999), エラーやバイアスを生成する 処理（すなわち簡便な処理）を自ら進んで行うと は想定されなかったためと考えられる。これに対 し, CEST は簡便な処理が適応上の利点を持っこ
とを主張し，その動機づけを想定する（Epstein et al., 1996). 本稿でも, 直観的処理への動機づけの 個人的要因が確認された。簡便な情報処理につい ては, 正確な認知を歪めるあのではなく, 望まし い結果を容易に得るものとして認識する必要があ るかもしれない，今後は，2過程それぞれの有用 性を検討することが求められよう。本尺度は, 高 合理性者ならびに高直観性者の情報処理を検討で きるあのであり，二重過程モデルのさらなる解明 に貢献しうると考えられる.

\section{引用文献}

Caccioppo, J. T., \& Petty, R. E. 1984 The need for cognition. Journal of Personality and Social Psychology, 42, 116-131.

Caccioppo, J. T., Petty, R. E., \& Morris, K. J. 1983 Effects of need for cognition on message evaluation, recall, and persuasion. Journal of Personality and Social Psychology, 45, 805-818.

Chaiken, S., \& Trope, Y. 1999 Dual-process theories in social psychology. New York: Guilford Press.

Epstein, S. 1994 Integration of the cognitive and the psychodynamic unconscious. American Psychologist, 49, 709-724.

Epstein, S., Denes-Raj, V., \& Pacini, R. 1995 The Linda problem revisited from the perspective of cognitive-experiential self-theory. Personality and Social Psychology Bulletin, 21, 1124-1138.

Epstein, S., Pacini, R., Denes-Raj, V., \& Heier, H. 1996 Individual differences in intuitive-experiential and analytical-rational thinking styles. Journal of Personality and Social Psychology, 71, 390-405.

今川民雄 1981 Ambiguity Tolerance Scale の構成 （1） 一 項目分析と信頼性について 北海道教育大学 紀要第一部 C 教育科学編, 32, 79-93.

Jaccard, J., \& Wan, C. K. 1996 LISREL approaches to interaction effects in multiple regression. California: Sage.

神山貴弥 2002 情報処理と説得: 精查可能性モデル 深田博己（編） 説得心理学ハンドブック—説得コ ミュニケーション研究の最前線 北大路書房 Pp. 418-455.

北村俊則・鈴木忠治 1986 日本語版 Social Desirability Scale について 社会精神医学, 9, 173-180. 
Pacini, R., \& Epstein, S. 1999 The relation of rational and experiential information processing styles to personality, basic beliefs, and the ratio-bias phenomenon. Journal of Personality and Social Psychology, 76, 972-987.

Petty, R. E., \& Caccioppo, J. T. 1984 The effects of involvement on responses to argument quality and quantity: Central and peripheral routes to persuasion. Journal of Personality and Social Psychology, 46, 69-81.

Petty, R. E., \& Wegener, D. T. 1999 The elaboration likelihood model: Current status and controversies. In $\mathrm{S}$. Chaiken, \& Y. Trope (Eds.), Dual-process theories in social psychology. New York: Guilford Press. Pp. 41-72.

酒井恵子 - 久野雅樹 1997 価值志向的精神作用尺度 の作成 教育心理学研究, 45, 388-395.

SASインスティチュートジャパン 1993 SAS/STATソフ

トウェアユーザーズガイド Version 6.
Smith, E. R., \& Decoster, J. 1999 Associative and rulebased processing: A connectionist interpretation of dual-process models. In S. Chaiken, \& Y. Trope (Eds), Dual-process theories in social psychology. New York: Guilford Press. Pp. 323-336.

豊田秀樹 1992 SAS による共分散構造分析 東京大学 出版会

豊田秀樹 1998 共分散構造分析入門編 朝倉書店

Tversky, A., \& Kahneman, D. 1982 Judgments of and by representativeness. In D. Kahneman, P. Solvic, \& A. Tversky (Eds.), Judgments under uncertainty: Heuristics and biases. New York: Cambridge University Press. Pp. 8498.

山本真理子・松井 豊・山成由紀子 1982 認知され た自己の諸側面の構造 教育心理学研究, 30, 64-68.

- 2003. 3. 6 受稿, 2004. 6. 11 受理一

\title{
Development of Rational and Intuitive Information-Processing Style Inventory
}

\author{
Mayumi Naito ${ }^{1,2}$, Kanae SuzukI $^{3}$ and Akira SAKAmoto ${ }^{4}$ \\ ${ }^{1}$ The Japan Society for the Promotion of Science \\ ${ }^{2}$ Ochanomizu University \\ ${ }^{3}$ Graduate School of Library, Information and Media Studies, University of Tsukuba \\ ${ }^{4}$ Faculty of Letters and Education, Ochanomizu University
}

The Japanese Journal of Personality 2004, Vol. 13 No. 1, 67-78

The aim of this study was to develop Information-Processing Style Inventory (IPSI), which measured individual differences in rational and intuitive thinking (Pacini \& Epstein, 1999). In Study $1(N=290)$, a confirmatory factor analysis was performed to examine the factorial validity of 38-item IPSI. Results confirmed that IPSI consisted of two factors; rationality and intuition. IPSI also had acceptable internal consistency and testretest reliability. Results of correlational analyses with other scales (ambiguity tolerance, theory orientation, self-esteem, and social desirability) showed high discriminant and convergent validity for IPSI. In Study 2 $(N=237)$, IPSI scores and probability-reasoning performance were examined to assess its construct validity. Results indicated that both rationality and intuition explained frequencies of corresponding reasoning error. In Study 2, a 24-item short version of IPSI was also developed and its reliability and validity were examined.

Key words: information-processing mode, individual differences, rational thinking, intuitive thinking, two factors 